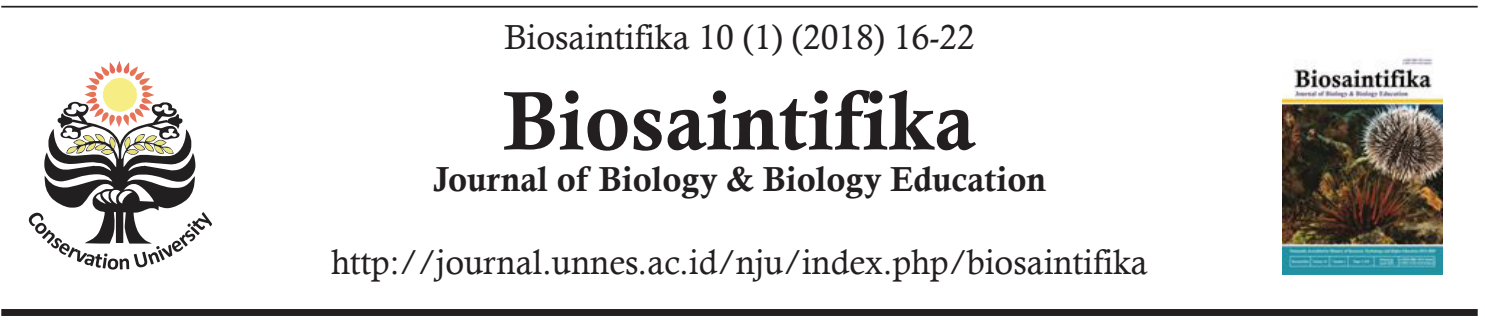

\title{
Ascaris suum Cuticle Ultrastructure Due to the In Vitro Application of Ethanol Extract to Fruits Musa x paradisiaca L. 'Pisang Ambon'
}

\author{
Dwi Haryatmi, ${ }^{\bowtie}$ Okid Parama Astirin, Tetri Widiyani
}

DOI: 10.15294/biosaintifika.v10i1.11918

Postgraduate Study Program, Universitas Sebelas Maret, Indonesia

\section{History Article}

Received 6 November 2017 Approved 17 December 2017 Published 30 April 2018

\section{Keywords}

Anthelmintic; Ascaris suum cuticle; Histopathology; Scanning electron microscope

\begin{abstract}
Species of Musa have various activities, one of which is anthelmintic activity. Part of banana plants that can be used as anthelmintic is part of the fruit, because of the phytochemical content possessed. Tannin is able to inhibit the enzyme cholinesterase, damage the membrane of the worm and can precipitate the protein. The purpose of this research is to know the content of tannin and also total tannin level on ethanol extract of Musa x paradisiaca L. 'Pisang Ambon' and in vitro effect of the extract on Ascaris suum cuticle. Thin Layer Chromatography (TLC) showed of ethanol extract of Ambon banana containing tannin with a total test of tannin was $54.98 \% \mathrm{w} / \mathrm{w}$. In vitro at negative control $(\mathrm{NaCl} 0.9 \%)$ worm death occurred at 289 hours, positive control (pyrantel pamoate $5 \mathrm{mg} / \mathrm{ml}$ ) at 1 hour, extract concentration $200 \mathrm{mg} / \mathrm{ml}$ at hour 27 and concentration $400 \mathrm{mg} / \mathrm{ml}$ at 1 hour. Histopathological examination and scanning electron microscope showed a degenerative change in ultrastructures of the worm's cuticle. From the results of this study, it can be concluded that exposure of ethanol extract to Ambon banana give a damaging effect to cuticle ultrastructure in the form of crack/break, perforation and separation of muscular from cuticle and edema on $A$. suum worm. High tannin content in the raw/green ambon banana, can be developed to eradicate ascariasis including egg stage which until now cannot be done with synthetic drugs due to the thickness and strength of layers of worm eggs consisting of layers of protein and lipids.
\end{abstract}

\section{How to Cite}

Haryatmi, D., Astirin, O. P. \& Widiyani, T. (2018). Ascaris suum Cuticle Ultrastructure Due to the In Vitro Application of Ethanol Extract to Fruits Musa x paradisiaca L. 'Pisang Ambon'. Biosaintifika: Journal of Biology \& Biology Education, 10(1), 16-22.

(C) 2018 Universitas Negeri Semarang
Correspondence Author:

Jl. Ir. Sutami No. 36A, Jebres, Surakarta, Central Java 57126

E-mail: parama_astirin@yahoo.com
p-ISSN 2085-191X

e-ISSN 2338-7610 


\section{INTRODUCTION}

Worm infection is an endemic and chronic disease caused by parasitic worms with high prevalence, non-lethal, but is capable of causing a decline in nutritional and public health conditions (Iman et al., 2015). Ascaris lumbricoides and Ascari ssuum are the most common intestinal worms found in humans and pigs. Eradication of infection of worms including ascariasis in Indonesia continues to be done until today. One of the methods used is by giving the anti-worm drug.

Research on the potential of plants as anthelmintic has been done. From several studies that have been done, obtained plants that have anthelmintic properties such as papaya, pare, temugiring, temu hitam, pin nut, cassava (Magdeleine et al., 2010; Tiwow et al., 2013). Williams et al., (2014) also has research on the anthelmintic effects of cocoa beans, pecan skin, pine bark, and white clover. Based on a study conducted by Iman et al., (2015), it was concluded that the concentration of Chinese leaf extract (Cassia alata L.) had a significant effect on mortality of adult female A.suum, and had $39.98 \%$ of Lethal Concentration $50\left(\mathrm{LC}_{50}\right)$. From in vitro testing by Tiwow et al., (2013), the ethanol extract of betel nut concentration of $10 \%$ able to make $A$. lumbricoides paralysis and at concentration of $20 \%$ able to make worm Ascaridia galli become lysis/die. Ethanol extract of betel seeds at a concentration of $30 \%$ had more effective anthelmintic power against $A$. lumbricoides worms and A. galli worms. Based on the results of other studies, papaya leaf extract is vermisidal to A. suum worms, in vitro with $\mathrm{LC}_{100}$ of $13.378 \%$ and $\mathrm{LT}_{100}$ of 54.706 hours. Papaya leaf extract is ovicidal to $A$. suum by direct contact in vitro. Venkatesh et al., (2013) showed that banana tree extract ethanol exhibited significant anthelmintic activity against Pheretimaposthuma worm, at concentrations of $100,50,25 \mathrm{mg} / \mathrm{ml}$ indicating the time of paralysis and death respectively at $42.33 \pm 1.45$ and $54.00 \pm 0.58 \mathrm{~min}, 74.33 \pm 1.20$ and $101.67 \pm 1.45,82.67 \pm 1.45$ and $115.00 \pm 1.73$.

Studies show that the species of Musa have various activities such as protecting from heartburn, immunomodulatory potential, anthelmintic activity, antidiabetic activity, antibacterial, antioxidant, anti-cancer, and anti-HIV activity (Joseph et al., 2014). In a study conducted by Malini et al., (2017) Musa x paradisiaca $L$ also included one of the plants used by the inhabitants of Karangwangi, Cianjur, West Java in treatment. In anthelmintic activity test of the banana extract by Venkatesh et al., (2013) of the phytochemical analysis showed a positive presence of tannins as well as flavonoids, glycosides, terpenoids, and sterols. According to research conducted by Ariani and Linawati (2016) ambon banana(Musa paradisiaca var. Sapientum (L.)) was known to contain saponins, glycosides, tannins, alkaloids, and flavonoids.

Tannin content can inhibit the enzyme cholinesterase and damage the membrane of the worm. Inhibition of enzyme work can cause the process of digestion metabolism disturbed so that worms will lack nutrients, in the end, worms will die from lack of energy. The membrane of worms damaged by tannin causes paralytic worms that eventually die (Tiwow et al., 2013). Traditionally, people have used Musa x paradisiaca L. Pisang Ambon' in the treatment of worms in animals. Therefore, it is critical to do the research to prove that other than to turn off the worms as anthelmintic, the ethanol extract of Ambon banana can cause damage to cuticle ultrastructure of A. suum worm.

Treatment by using herbs will be an alternative to prevent the occurrence of ascariasis. Banana plants are widely available in all regions in Indonesia make the treatment effort that is easy to get, lower price, and when used appropriately then the side effects caused smaller when compared with the use of synthetic drugs.

\section{METHOD}

The research was conducted at Parasitology Laboratory of Faculty of Medicine, Gadjah Mada University (UGM) Yogyakarta, Anatomy Pathology Laboratory of Faculty of Veterinary Medicine of UGM. The examination of the secondary metabolite was done at UGM Integrated Research and Testing Laboratory, Scanning Electron Microscope (SEM) done at Zoology Research Center of Lembaga Ilmu Pengetahuan Indonesia (LIPI) Cibinong, from February to June 2017. The primary tools used are UV-Vis spectroscopy, microtome, floating bath, tissue processor, JEOL JSM-5310LV Scanning Electron Microscope.

Ethanol extract of Ambon banana which has been tested by phytochemical screening, identification of tannin with TLC and continued test of total tannin level. Adult $A$. suum worms were obtained from the slaughterhouses of Radhajaka pigs in Jagalan, Surakarta. The worms obtained were divided into five groups. The first group was used for determination, the second group as the negative control. The group when the positive control and group of 4.5 were used for the in vitro treatment of the banana extract ethanol concentration of $200 \mathrm{mg} / \mathrm{ml}$ and $400 \mathrm{mg} / \mathrm{ml}$, were 
then used in the manufacture of histopathologic pr Scanning Electron Microscopy for ultrastructure observation of the cuticle after treatment.

\section{Identification of Tanin Compound with TLC and Tanin Level Test}

The banana ethanol extract was carefully weighed, extracted with $10 \mathrm{ml}$ of diethyl ether for 20 hours, dried with filter paper. The obtained residue was boiled with $5 \mathrm{ml}$ of distilled water for 2 hours, then cooled and filtered. Conducted a $10 \mu 1$ spot spoting on the silica gel plate and then inserted the plate into the saturated chamber of the ethyl acetate-acetic acid-formic acid (100-1111-27) phase of motion. Brought to the limit and then dried the plate and observed under UV light then sprayed with ferric chloride reagent.

The tannin content of the ethanol extract of the ambon banana was determined by ultraviolet-visible spectrophotometry method using Folin Ciocalteu reagent based on the complex formation of molybdenum-tungsten blue. The hydroxyl group in the phenolic compound reacts with the Folin Ciocalteu reagent forming a blue molybdenumtungsten complex and can be measured uptake at visible light areas at $760 \mathrm{~nm}$ wavelength with a reaction time of $30 \mathrm{~min}$ (Malangngi et al., 2012).

\section{Preparation of Histology Preparations}

The worms were fixed with $10 \%$ formalin solution for 24 hours. After that worm cutting approximately one $\mathrm{cm}$. Dehydration process on tissue processor using alcohol 80\% (2 hours), 95\% (2 hours), 95\% (1 hour), absolute alcohol (3x1 hours). Next clearing using xylol (3x1 hours) followed by impregnation using paraffin $(3 \times 2$ hours). Embedding is done by moving a network that is in embedding cassette into the base mold then filled with liquid paraffin, then attached to a $3 \times 3$ $\mathrm{cm}$ block of wood. Cutting is done using microtome with a thickness of $6 \mu \mathrm{m}$, taken with glass object then dried.

The stage of deparaffinization, i.e., by inserting preparations into xylol ( $2 \times 5$ minutes). The preparations are rehydrated by immersion into an absolute ethanol solution $(2 \times 1 \mathrm{~min}), 95 \%$ ethanol $(2 \times 1 \mathrm{~min})$ then dyed with aquades. Stain preparations using hematoxylin and eosin. The result is observed under a light microscope (Suwiti, 2010).

\section{Scanning Electron Microscopy}

Scanning electron microscopy is performed on the worm's cuticle. Samples were fixed with absolute ethanol to be sent to the Zoology Research Center of Lembaga Ilmu Pengetahuan Indonesia
(LIPI) Cibinong. To conduct SEM, sample preparation performed there are seven stages. The first stage is the cleaning stage, the sample soaked in caccodylate buffer approximately 2 hours agitated in an ultrasonic cleaner for 5 minutes. The second stage is prefixation; the sample is put into $2.5 \%$ glutaraldehyde solution several hours to 2 days. The third stage is a fixation, the sample soaked in tannic acid $2 \% 6$ hours to a few days then washed with cacodylate buffer for 15 minutes, washing repeated until 4 times followed by aquades for 15 minutes. The fourth stage is the dehydration stage, the sample is immersed in 50\% alcohol for 5 minutes repeated up to 4 times, $70 \%$ alcohol for 20 minutes, $85 \%$ alcohol for 20 minutes, $95 \%$ alcohol for 20 minutes, 10 minutes absolute alcohol 2 times done at room temperature. The fifth stage is drying, the sample soaked in butanol tart for 10 minutes 2 times, then frozen in the freezer until frozen, then put into frozen drier or vacuum dryer until dry. The sixth stage is the mounting, the sample is glued to the stub specimens according to need or desire, the seventh stage of the coating with $\mathrm{Au}$ using the ion coater device and the scanning electron microscope JEOL JSM-5310LV (Goldstein et al., 1992).

\section{RESULTS AND DISCUSSION}

\section{Identification of Tanin Compound with TLC and Tanin Level Test}

The presence of tannin content shown in the TLC results seen in Figure 1, showed the same rf value between standard tannin and ethanol extract of Musa x paradisiaca L. 'Pisang Ambon'. In the total test of tannin, the ethanol extract of Ambon banana has a content of $54.98 \% \mathrm{w} / \mathrm{w}$. The process of tannin extraction on bananas is based on the principle or character of the tannin itself soluble in the polar solvent. This is supported by Cannel (1998) in Askadilla et al., (2015) that tannins are a mixture of polyphenols in plants that form glycosides, and tannins are polar in glycoside form, while ethanol is a polar solvent that is more effective in attracting tannins than with both semipolar and nonpolar solvents.

\section{Histopathology Preparation}

Damage of $A$. suum worm ultrastructure on negative controls that died at 289 hours, positive control at 1 hour ( $60 \mathrm{~min})$, ethanolic extract treatment of Ambon banana concentration 200 at 27 hours and $400 \mathrm{mg} / \mathrm{ml}$ at hour to-1 (60 minutes) is shown in Figure 2.

Ascari ssuum exposed to ethanol extract of ambon bananas paralyzed and then died. The ef- 

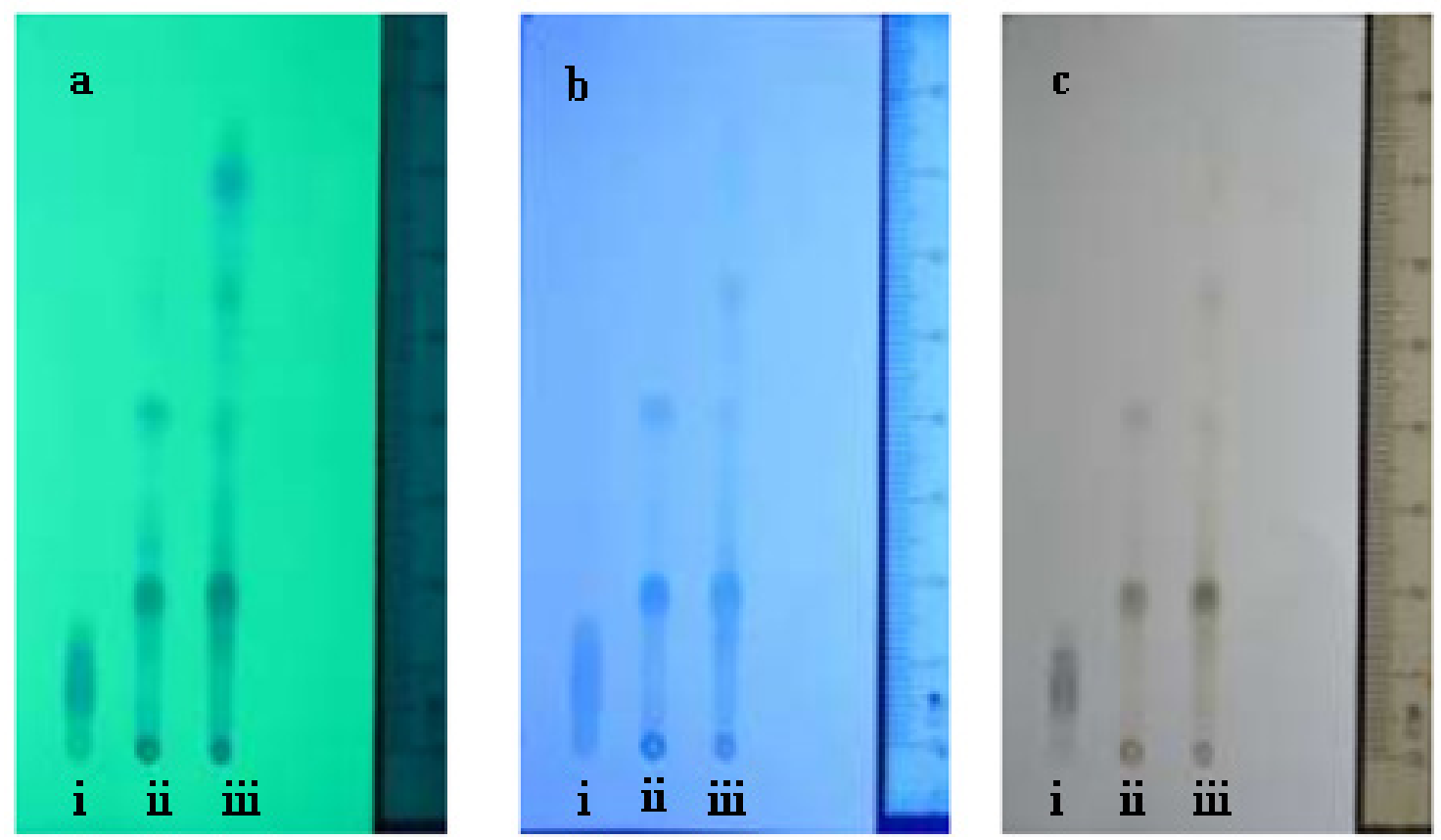

Figure 1. Tests of tannins group identification with TLC method; (a). UV readings are $254 \mathrm{~nm}$, (b). Readings on UV 365 nm; (c). Visible Readings. (i): Comparator Tannic Acid; (ii): Extract (Fruit / Banana Meat); (iii): Extract (Banana Skin)

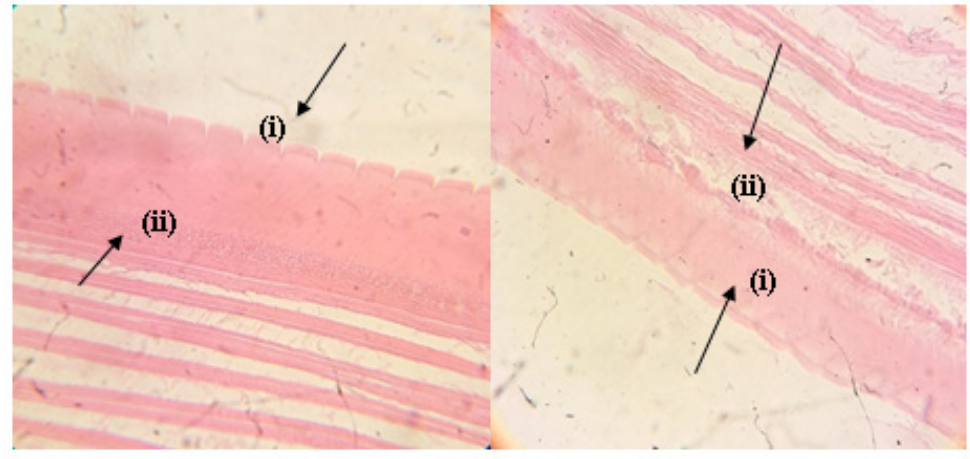

(a)

(b)

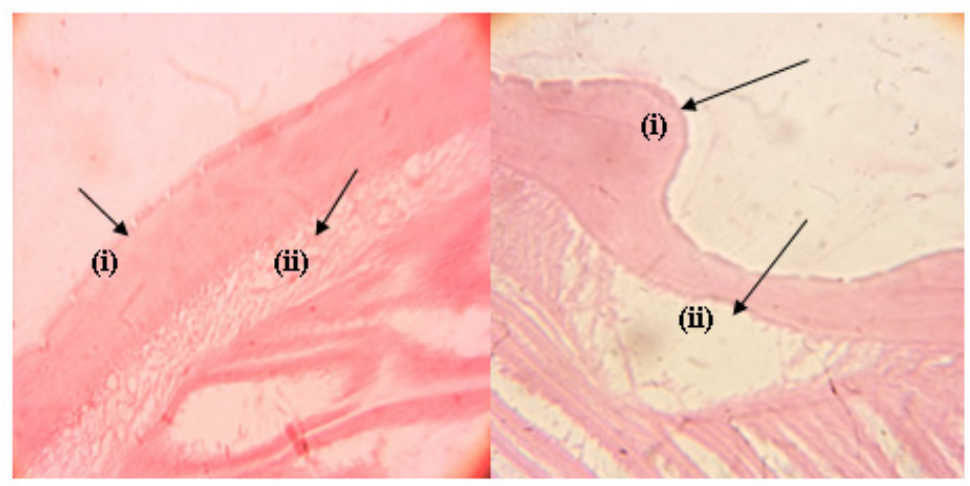

(c)

(d)

Figure 2. Histopathological structure of the cuticle surface of 400x magnification; (a). Negative control (NaCl 0.9\%): (i) Cuticle looks flat, (ii) Cuticle seen linked with muscular; (b). Positive control (pyrantel pamoate $5 \mathrm{mg} / \mathrm{ml}$ ): (i) Cuticle looks flat, (ii) Cuticle seen separately with muscular; (c). Treatment of extract $200 \mathrm{mg} / \mathrm{ml}$ : (i) Cuticle looks flat, (ii) Cuticle seen apart with muscular; (d). Treatment of the extract $400 \mathrm{mg} / \mathrm{ml}$ : (i) The cuticle looks uneven, (ii) The cuticle is seen separately with the muscular and occurs edema. 
fect of exposure on the cuticle/worms of the negative control group indicates no damage, the $\mathrm{cu}$ ticle looks smooth and flat. The positive control, cuticle looks flat but cuticle seen apart with muscular as well as treatment of extract concentration $200 \mathrm{mg} / \mathrm{ml}$, while at level $400 \mathrm{mg} / \mathrm{ml}$ showed cuticle which is uneven, separated by muscular and also happened oedem.

The body wall of the nematode consists of the cuticle, hypodermis, and muscle wall of the body. The outermost layer is the cuticle, the polysaccharide complex structure whose function is essential for animals (Pandey et al., 2013; Roberts and Janovy, 2009). Cuticle worms have an important role as a protective laver and are also used as absorption of nutrients in the host. When the cuticle is damaged by anthelmintic treatment, it can disrupt the worm defense system.

\section{Scanning Electron Microscopy}

Scanning electron microscopy of the anterior cuticle of the lips and interlabial or posterior parts of the worms seen in Figure 3. The worm cuticle on the negative controls is smooth, no damage. In contrast to worm cuticles on positive controls and worm cuticles with exposure to ethanol extract of ambon bananas, experiencing the occurrence of blisters, cracks and potholes. Cuticle damage due to exposure to extracts appears to be more widespread and more in line with the concentra-

(a)
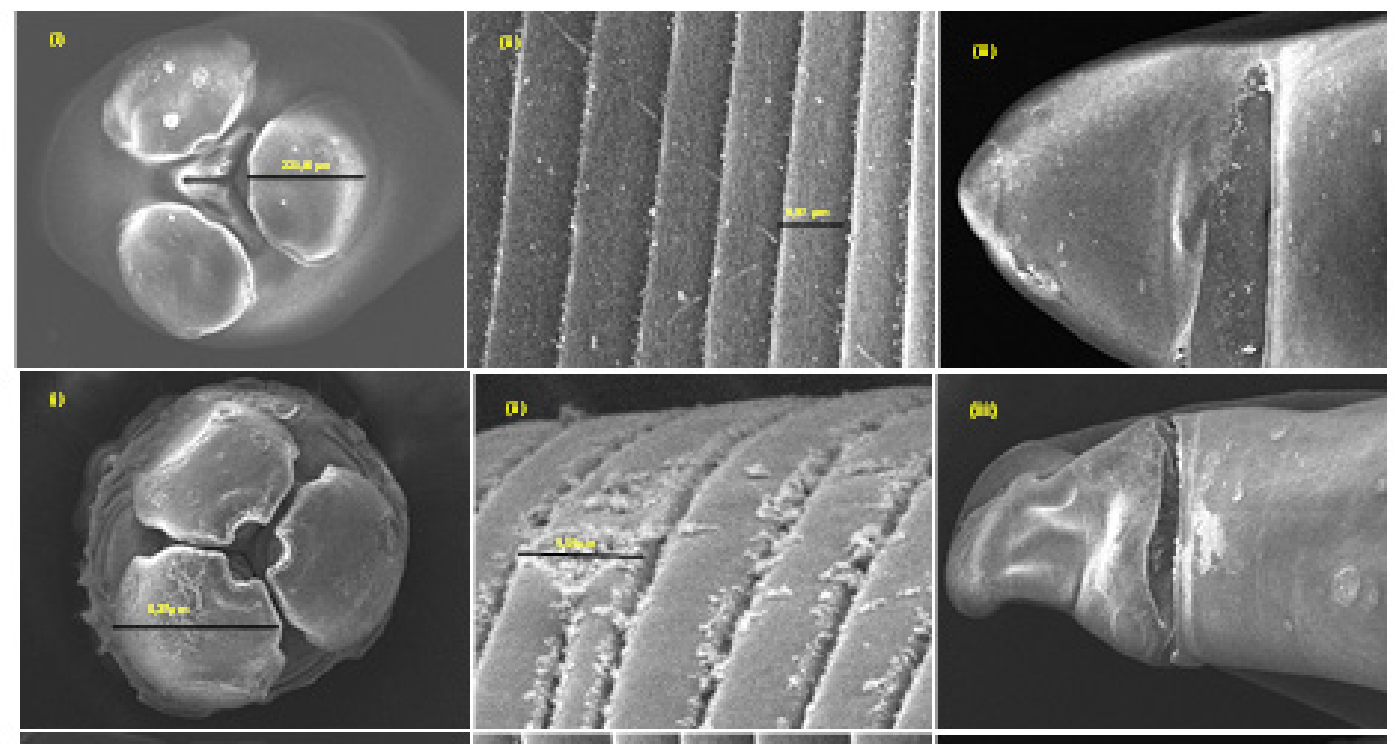

(c)
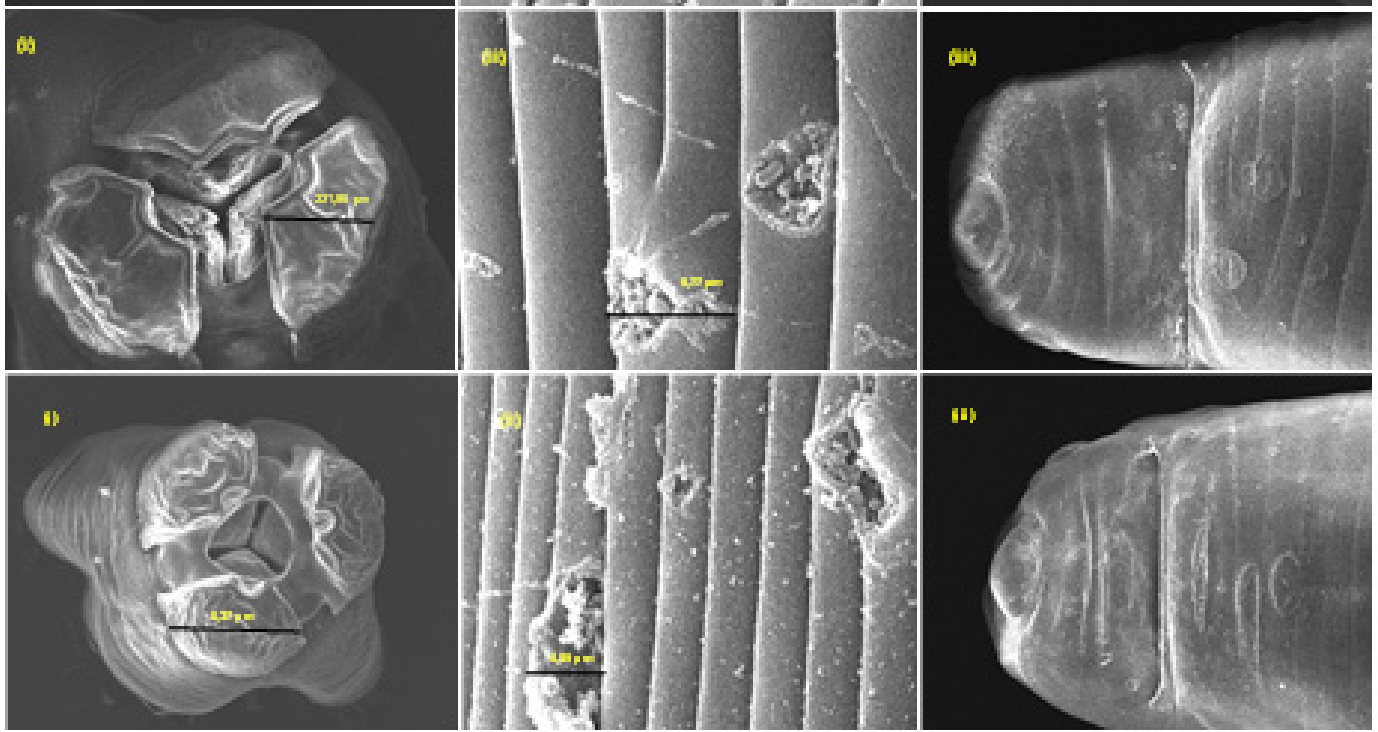

Figure 3. Scanning Electron Microscope Ascaris suum Worm; Negative control (NaCl 0.9\%): (i) Anterior lips and interlabia worms, (ii) Cuticle (iii) Posterior anal worms;Positive control (pyrantel pamoate 5 $\mathrm{mg} / \mathrm{ml}$ ): (i) Anterior lips and interlabia worms, (ii) Cuticle (iii) Posterior anal worms; Treatment of extract $200 \mathrm{mg} / \mathrm{ml}$ : (i) Anterior worm lips and interlabia, (ii) Cuticle (iii) Posterior anal worms section; Treatment of extract $400 \mathrm{mg} / \mathrm{ml}$ : (i) Anterior worm lips and interlabia, (ii) Cuticle (iii) Posterior anal worms section. 
tion of extracts.

This study is supported by other research on the potential of various plants with its phytochemical content as anthelmintic which also causes the occurrence of surface damage of the worms/cuticle worms which are a rough extract of Flaminga vastita causing damage to cuticle and muscle of Ascaris suum body (Yadav et al., 1992). The extract of the Lasimachia ramosa plant causes death, the visible worm body shrinks, and surface changes in Ascaris suum and Fasciola buski (Challam et al., 2010) and antimmintic activity of Trigonella Foenum-graecum produce swelling, blisters in the Gastrothylax crumenifer (Swarnakar et al., 2014). The efficacy of Citrullus colocynthis fruit extracts on Orthocoelium scoliocoelium also show damage, blisters and cracks in the calendar, vacuolization of parenchymal cells, separation of the muscle and acetabulum (Swarnakar and $\mathrm{Ku}$ mawat, 2014). Swargiary, 2015 also showed damage to the worm cuticle Faciolopsis buski possible because of bioactive content in the plant Alpinia nigra.

Another study by Challam et al., (2012) compared with control, parasite Raillietina echinobothrida treated ethanol extract Carex baccans showed extensive distortion and topography surface topography destruction, muscle layer disorder, vacuolization of the thickened layer, and swelling. Alcohol extracts from Acacia oxyphylla and Securiniga virosa lead to morphological changes in the cestode parasite, $R$. Echinobothrida (Dasgupta et al., 2013). In the same way, the surface of blisters and severe lesions were observed in $F$. gigantica when the parasite was incubated with Siwa propolis extract (Hegazi et al., 2007). The surface change in Fasciola hepatica when treated with genistein, consists of swelling and blisters, especially in the posterior region and also the release of thorns (Toner et al., 2009).

Tannin toxicity can damage the membrane, meaning tannin has the ability to cause damage when it comes to the worm's cuticle. Tanin will interfere with the permeability of the cell itself. Due to disruption of the permeability, the cell cannot perform life activities so that metabolism is inhibited. According to Pandey et al., (2013) worms have no way of storing energy, so the worms will eat continuously to meet their metabolic needs. Therefore the disruption of the process of eating and also the occurrence of paralysis due to exposure to active substances that cause damage will cause the death of worms. Tannins derived from polyphenol compounds also have the ability to precipitate proteins. These findings can be developed in studies for the eradication of ascariasis including the egg stage that until now has not been possible with synthetic drugs.

\section{CONCLUSION}

From the results of this study, it was concluded that from exposure to ethanol extract to Ambon banana as anthelmintic gave effect to the ultrastructure damage on the cuticle of $A$. suum worm.

\section{REFERENCES}

Ariani, K. J. \& Linawati, Y. (2016). Efek Pemberian Jus Buah Pisang Ambon (Musa paradisiaca var. sapientum (L.) Kunt.) terhadap Kadar Glukosa Darah Tikus Jantan Galur Wistar yang Terbebani Glukosa. Jurnal Farmasi Sains dan Komunitas, 13(1), 1-6.

Askadilla, W. L., Sidharta, B. B. R., \& Pranata, F. S. (2015). Aktivitas Antibakteri Ekstrak Daun Kana (Canna coccinea) terhadap Pseudomonas aeruginosa dan Staphylococcus aureus dengan Variasi Pengekstrak. Tesis. Yogyakarta: Fakultas Teknobiologi, Universitas Atmajaya Yogyakarta.

Challam, M., Roy, B., \& Tandon, V. (2010). Effect of Lysimachia ramosa (Primulaceae) on Helminth Parasites: Motility, Mortality and Scanning Electron Microscopic Observation of Surface Topography. Veterinary Parasitol, 169 (1-2), 214218.

Challam, M., Roy, B., \& Tandon. (2012). In Vitro Anthelmintic Efficacy of Carex baccans (Cyperaceae): Ultrastructural, Histochemical and Biochemical Alterations in the Cestode, Raillietina echinobothrida. Journal of Parasitic Diseases, 36(1), 81-86.

Dasgupta S., Roy B., Venkataswamy, M., \& Giri B.R. (2013). Effects of Acacia oxyphylla and Securinega virosaon Functional Characteristics of Raillietina echinobothrida (Phylum: Platyhelminthes; Class: Cestoidea), A Poultry Cestode Parasite. Journal of Parasitic Diseases, 37(1), 125-130.

Goldstein, J. I., Newbury, D. E., Echlin, P., Joy, D.C., Romig, A. D. JR., Lyman, C. E., ... \& Lifshin, E. (1992). Scanning Electron Microscopy and X-ray Microanalysis : A Text for Biologist, Materials Scientist, and Cytologists. New York: Plemun Press.

Hegazi A. G., Abd el-Hady F. K., \& Shalaby H. A. (2007). An In Vitro Effect of Propolis on Adult Worms of Fasciola gigantica. Veterinary Parasitol, 144(3-4), 279-286.

Iman, F., Waluyo, J., \& Asyiah, I. N. (2015). Pengaruh Variasi Konsentrasi Ekstrak Daun Ketepeng Cina (Cassis alata L.) terhadap Mortalitas Cacing Ascaris suum Dewasa secara In Vitro. Pancaran, 4(2), 71-82.

Joseph, J., Sindhu, T. J., Vincent, G., Paul, D., Kumar, B. D, Bhat, A. R \& Krishakumar, K. (2014). 
Review on InVivo and In Vitro Studies on The Pharmacological Activities of Musa Spesies. World Journal of Pharmacy and Pharmaceutical Sciences, 3(2), 1133-1142.

Magdeleine, C. M., Udino, L., Philibert, L., Bocage, B., \& Archimede, H. (2010). Invitro Effects of Cassava (Manihot esculenta) Leaf Extracts on Four Development Stages of Haemonchus contortus. Veterinary Parasitology, 173(1-2), 85-92.

Malangngi, L.P., Sangi, M. S., \& Paendong, J. J. E. (2012). Penentuan Kandungan Tanin dan Uji Aktivitas Antioksidan Ekstrak Biji Buah Alpukat (Persea americana Mill.). Jurnal MIPA UNSRAT ONLINE, 1(1), 5-10.

Malini, D. M., Madihah, J. K., Fitri K., \& Johan I. (2017). Ethnobotanical Study of Medicinal Plants in Karangwangi, District of Cianjur, West Java. Biosaintifika Journal of Biology \& Biology Education, 9 (2), 345-356.

Pandey, K. h., Khadka, P., Thapa, S. K., Baral, P., Pandit, A., \& Panta, S. (2013). Analysis of Anthelmintic Activity of Crateva unilocularis Buch.-Ham. Leaf. World Journal of Pharmacy and Pharmaceutical Sciences, 2(6), 4443-4448.

Roberts, L. S. \& Janovy, J. Jr. (2009). Foundations of Parasitology. McGraw-Hill Companies, New York.

Suwiti, N. K. (2010). Deteksi Histologik Kesembuhan Luka pada Kulit Pasca Pemberian Daun Mengkudu (Morinda Citrofilia Linn.) Buletin Veteriner Udayana, 2(1), 1-9.

Swargiary. A. (2015). Astragalin, The Active Component of Alpinia nigra and its Effect on Tegumental Ultrastructure of Fluke Parasite, Fasciolopsis buski. International Journal of Pharma and Bio Sciences, 6(4), 395-403.

Swarnakar, G. \& Kumawat, A. (2014). In Vitro Anthel- mintic Effect of Citrullus colocynthis on Tegument of Amphistome Orthocoelium scoliocoelium (Trematoda: Digenea). International Journal of Current Microbiology and Applied Sciences, 3(6), 571-582.

Swarnakar, G., Roat, K., Sanger, B., \& Kumawat, A. (2014). Anthelminthic effect of Trigonella foenum-graecum on Tegument of Gastrothylax crumenifer in Cattle of Udaipur. International Journal of Current Microbiology Applied Sciences, 3(5), 599-606.

Tiwow, D., Bodhi, W., \& Kojong, N. S. (2013). Uji Efek Antelmintik Ekstrak Etanol Biji Pinang (Areca catechu) terhadap Cacing Ascaris lumbricoides dan Ascaridia galli secara In Vitro. PHARMACON Jurnal Ilmiah Farmasi UNSRAT, 2(02), 76-80.

Toner E., McConvery F., Brennan G.P., Meaney M., \& Fairweather I. (2009). A Scanning Electron Microscope Study on The Route of Entry of Triclabendazole into The Liver Fluke Fasciola hepatica. Parasitology, 136(5), 523-535.

Venkatesh, Krishna, V., Kumar, K. G., Pradeepa, K., Kumar, S. R. S., \& Vijay, K. (2013). Anthelmintic Activity of Musa paradisiaca (L.) cv. Puttabale. International Journal of Pharmaceutical Sciences and Drug Research, 5(2), 67-69.

Williams, A. R., Fryganas, C., Ramsay, A., Harvey, I. M., \& Thamsborg, S. M. (2014). Direct Anthelmintic Effects of Condensed Tannins from Diverse Plant Sources Against Ascaris suum. PLOS One, 9(5), 1-16.

Yadav, A. K., Tandon, V., \& Rao, H. S. P. (1992). In Vitro Anthelmintic Activity of Fresh Tuber Extract of Flaminga vestita Against Ascaris suum. Fitoterapia, 8(5), 395-398. 